\title{
The Subaltern's ${ }^{1}$ Prerogative: A Postcolonial Reading of Laila Lalami's The Moor's Account ${ }^{2}$
}

\author{
Hamid Issafi \\ Department of English studies, Faculty of Letters and Human Sciences, Mohammed V University - Rabat, \\ Morocco
}

\begin{abstract}
Author's bio: Hamid Issafi is a doctoral student conducting his doctoral research under the supervision of Professor Dr. Abdelghanie Ennam from the Department of English studies, Faculty of Letters and Human Sciences, Mohammed V University, Rabat, Morocco. Hamid holds an MA degree in General Literature and Comparative Criticism from the same university.

Acknowledgements: I would like to express my gratitude and special thanks to my doctoral research supervisor Professor Dr. Abdelghanie Ennam for his pertinent remarks, valuable instructions and guidance. Special thanks to the anonymous IISTE peer reviewers.
\end{abstract}

\begin{abstract}
A number of Arab immigrant writers opt for writing in the language of the host countries. They give much emphasis to the relationship between the Western subject and the Other, among whom is the writer Leila Lalami. The chief concern of this paper is to present a reading of Leila Lalami's The Moor's Account from a Post-Colonial perspective. Not only does the voicing of Mustafa from Lalami's part become the embodiment of resistance of the occlusion of the Other, but it also brings forth an unsaid history of the sixteenth century into a twenty-first century setting. In this sense, storytelling becomes - on the one hand - an essential element in self-assertion and identity forming. On the other hand, the subaltern's ability to speak is an act of survival among the indigenous tribes.

Keywords: Post-colonialism - voicing - hybridity - double-colonization - identity -small narratives - storytelling. DOI: $10.7176 / \mathrm{JEP} / 10-23-17$
\end{abstract}

Publication date: August $31^{\text {st }} 2019$

\section{Introduction}

The aim of this paper is to present a postcolonial reading of Laila Lalami's The Moor's Account. I will approach the novel from three main angles. First, I will argue for the rewriting or representation of history from the perspective of a slave. Second, I will shed light on symbolism, namely the signification of 'the creaky blue door'; I will also cast a glimpse on Moroccan culture so as to foreground the anthropological side of the novel. Third, much emphasis will be put on storytelling as an interpolation of the power relations between master and slave. As such, it is an act of survival among the indigenous tribes. Of paramount importance, too, is Estebanico's usurpation of the role of the traditional healer. Methodologically speaking, my analysis will be premised upon Postcolonial theory; I will, thus, deploy notions that are akin to Postcolonial theory, such as 'hybridity', 'double-colonization', 'subaltern' and 'small narratives'. I will use them as tools of analysis. As for the aesthetics of the novel, I will also shed light on some of the narrative techniques disseminated in The Moor's Account by Laila Lalami.

To begin with, Laila Lalami is a Moroccan American novelist and essayist. In 1992, she completed her doctoral dissertation in the University of Southern California. She is deeply concerned with exile and migration issues. Most of her notable works of fiction are Hope and Other Dangerous Pursuits (2005), Secret Son (2009), and The Moor's Account (2014). In 2015, she was finalist for the latter novel for the Pulitzer Prize. She is currently a professor of creative writing at the University of California, Riverside.

As far as the plot of the novel is concerned, in 1527, a Spanish Armada of five ships and over six hundred soldiers, sailors and colonists under the leadership of Panfilo de Narvaez sailed from Spain to colonize the lands from Florida Westwards. King Charles V appointed Panfilo de Narvaez governor by proxy. In this context, Said Allouch asserts that Narvaez "was one of old assistants of Hernan Cortes and Ponce de Leon; he lost his right eye under their command." "3 Throughout the trajectory of the expedition, the conquistadors underwent calamities and devastating circumstances. Ultimately only four men survived the expedition: Alonso del Castillo Maldonado, Alvar Nunez Cabeza de Vaca, Andres Dorantes, and Estebanico, a slave from Azemor. In his historical account

\footnotetext{
1 - I inspired the notion of the Subaltern from Gayatri Chakravorti Spivak's article « Can the Subaltern Speak ? », from Colonial Discourse and Post-Colonial Theory: A Reader, edited by Patrick Williams and Laura Chrisman, New York: Colombia University Press, from: http://planetarities.web.unc.edu/files/2015/01/spivak-subaltern-speak.pdf In this article, Gayatri Spivak draws upon Antonio Gramsci's work on the 'subaltern classes'. P78.

2 - Laila Lalami, The Moor's Account, Periscope Edition : Reading, The United kingdom, 2015.

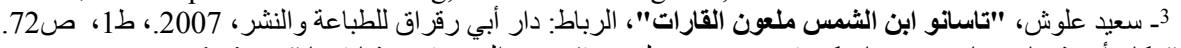

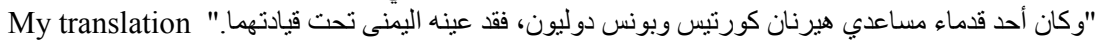


of the expedition, Cabeza de Vaca allocated much room for the voices of his companions save for Estebanico's voice, which was supressed as he was scarcely mentioned.

In response to this, in her novel, The Moor's Account, Laila Lalami intertwined history with fiction so as to grant Estebanico a voice to re-write history of the New World. In the prologue of the novel the hero Mustafa ibn Muhammed ibn Abdussalam al-Zammori, known among his companions as Estebanico, made a statement of purpose. He affirms that his testimony was pigeonholed by the three Castilian gentlemen. Their accounts were subject to inclusion and exclusion of certain details due to the constraints of society. However, Mustafa acted by his free will as he did not have to abide by the rules of society.

\section{I- Representation of history from a postcolonial perspective:}

In her novel, The Moor's Account, Laila Lalami breaks the linearity of the traditional narrative structure. Instead of having beginning, rising action, climax, denouement and end, Lalami opted for in medias res technique, which means that the beginning is in the middle as the novel starts with the landing of Narvaez expedition in La Florida and puts much emphasis on the massacre of the Indians by the Castilian conquistadors. Two stream structures are interwoven together to form the narrative frame. To solve this problematic, Lalami adopts two narrative techniques: flashback and flash-forward. The narrator Mustafa relates the events in retrospection. In the second chapter, which is entitled "The Story of My Birth", he narrates how his family moved to Azemmur and the circumstances in which he was born. The third chapter "The story of the Illusion" opens up with the burial of the three Castilians who were killed in the Battle of Rio Oscuro; whereas chapter four is devoted to "the Story of Azemmur". The trajectory of the narrative, therefore, alternates back and forth between two different settings: the setting of Azemmur and that of the New World.

Apart from these narrative techniques, Laila Lalami resorts to stream of consciousness to reveal what is going on in the mind of the protagonist Mustafa. An instance of this is when Narvaez' soldiers abducted the women and girls of Apalache, the consequence of which was an ambush by the Indian men who were armed with hatchets, bows, spears and lances. They rushed to free their wives. Mustafa unconsciously voiced his monologue:

"Return their women, I silently begged. Return their women. Senor Dorantes turned toward me. What did you say, Moro?

I had not realized that I had spoken out loud, so for a moment I looked uncomprehendingly at my master's surprised face."1

At the sight of the Indian men who started making delirious cries, Mustafa expected matters to go worse.

In investigating the archive of official history, Laila Lalami found out that a slave from Azemmur, baptized in Spain as Estebanico, was mentioned along with the three other Castilians: Alvar Nunez Cabeza de Vaca, Alonso del Castillo Maldonado, and Andres Dorantes de Carranza. Their testimonies were recorded and taken for granted; whereas Estebanico's voice was silenced. In her attempt to restore Mustafa's voice, Lalami resorts to one of the strategies common in Postcolonial studies, which is that of debunking the Western mega-narratives that tend to marginalize non-Western narratives.

In line with this, in his The Postmodern Condition: A Report on Knowledge ${ }^{2}$, Jean François Lyotard hails meta-narratives with scepticism for their totalitarian force. For him, they are not tenable as they are reductionist and teleological. Thus, Lyotard proposes that meta-narratives should allow small narratives to emerge.

In this sense, Lalami's The Moor's Account is a re-presentation of a representation. In intertwining history and fiction, Lalami designed The Moor's Account in the form of a sixteenth-century manuscript or travelogue as she makes use of certain devices, some of which are as follows. First, she starts the prologue of the novel with the 'bassmala', a formality that prevails in most ancient Arabic scriptures and manuscripts. Second, no quotation marks are used in dialogues.

Finally, in recording his account about the expedition, instead of the Gregorian calendar, the narrator adopts the Islamic or Hijri calendar that starts from the migration of Muslims from Mekkah to the Madinah to flee from persecution. Mustafa's choice of the Hijri calendar stems from the fact that his account of Narvaez expedition was meant for Moroccan readership upon his would-be return.

In his article, "'Whichever way you turn, there is the face of God' diaspora, memory, and historiography from the margin in The Moor's Account by Laila Lalami", Abdellah Elboubekri asserts that "the most common method for historical reconstruction is the excavation of buried accounts of the subordinated subjects in society." 3

In the above-mentioned article, Abdellah Elboubekri puts much emphasis on the importance of diasporic

\footnotetext{
1 - Laila Lalami, The Moor's Account, Reading: Periscope Edition, 2015. P121.

2 - Jean François Lyotard, The Post-Modern Condition : A Report on Knowledge, Translation from French by Geoff Benington and Brian Massumi, Forward by Fredric Jameson, Manchester: Manchester University Press, 1984, Volume 10, Pp 120-126. Pdf format please see: https://www.abdn.ac.uk/idav/documents/Lyotard_-_Postmodern_Condition.pdf

3 - Abdellah Elboubekri, "'Whichever way you turn, there is the face of God' diaspora, memory, and historiography from the margin in The Moor's Account by Laila Lalami”, an article published in African and Black Diaspora: An International Journal on September $3^{\text {rd }}$, 2016. P5.
} 
memory in Laila Lalami's The Moor's Account. His thrust of argument is that diasporic memory can serve as a double-fold medium. On the one hand, it is a crucial device in historical reconstruction. On the other hand, it is "an arena for the contention over authority and the negotiation of power relationship between the master and slave discourses."

In his chronicle, The Journey of Alvar Nunez Cabeza de Vaca ${ }^{2}$ (1542), Cabeza de Vaca depicts the conquistadors as being peaceful to the Indians; he even concealed the crimes and massacres committed against the indigenous tribes as they entered La Florida:

"We inquired of the Indians (by signs) when they gave us to understand that, very far from there, was a province called Apalachen in which there was much gold."3

Thus, the Western conquistadors are represented as being gentle to the Indian and devoid of any cruelty and disgrace. The image of the good white men emerges once more upon reaching Apalache as Cabeza de Vaca narrates in his historical account:

"Upon penetrating into the village (Apalache) we found only women and boys. The men were not there at the time, but soon, while we were walking about, they came and began to fight, shooting arrows at us. They killed the inspector's horse, but finally fled and left us."4

The Castilian soldiers were so sympathetic that they returned women and children to the Indian men. However, as a counter view, Laila Lalami intended to fill in the historical lacunae inscribed within Cabeza de Vaca's chronicle. So, by dint of memory, Mustafa Zemmuri recalls reminiscent past events sometimes fraught with nostalgia to his homeland. His concern is to correct and fill in the aporias of Cabeza de Cabeza de Vaca's chronicle. The quest and greed for gold, silver and the riches of the kingdom of Apalache were strong incentives for the Castilian soldiers to annihilate the Indian aboriginals. As a result, four Indians were captured, interrogated and tortured to reveal the location of the dreamt of Apalache. Upon entry to Apalache, Narvaez's soldiers abducted Indian women and children, and looted crops and anything of value although some captains gave sound arguments that gold and precious stones do not exist in Apalache:

"My son, the commissary said. He spoke kindly, as if he were about to invite a confession or comfort a gravely injured man. My son, I do not believe the Indians are hiding gold. If they did indeed have gold, their dwellings would not be made of straw and their women and children would not be naked." 5

However, Narvaez did not take into consideration the commissary's advice, "in short, he attempted to govern." Consequently, his obstinacy and reluctance to free the Indian women and children led to the killing of fifteen Indians. What is more, inhumanity and savagery of the whites are inscribed within Mustafa's version of history. In one of the shocking scenes he depicts the raping of Indian girls and young women.

Still, Laila Lalami deployed strategies that are common place in Postcolonial studies, among which is the dismantling and debunking of the Western mega-narratives or totalitarian discourses, for they are, in Jean François Lyotard's point of view ${ }^{7}$, teleological and reductionist. Lyotard suggests, instead, giving much room for small narratives to emerge. Likewise in his Culture and Imperialism, Edward Said attests to the totalitarian aspect of human History: "Now I am temperamentally and philosophically opposed to vast system building or to totalistic theories of human history." "In this sense of the word, The Moor's Account is a re-presentation of a representation; I hereby argue that small narratives can play a pivotal role in bringing to the fore unbiased representation of women.

By the same token, representation of women cannot be put in the pigeonhole. Of paramount importance is the focalisation of the story of Ramatullai. Such a small narrative sheds light on a large category of women who belong to formerly colonized countries. I argue that narration here serves as a strategy "to induce alternative narratives to emerge, such as narratives of liberation and emancipation." "Lalami devoted a whole chapter to "The Story of Ramatullai' to allow her to tell her story, which epitomizes the suffering and despair of thousands of

\footnotetext{
1 - ibid, p2.

2 - Alvar Nunez Cabeza de Vaca, The Journey of Alvar Nunez Cabaza de Vaca (1542), translated from his Own Narrative by Fanny Bandelier, New York: A. S. Barnes and Company, 1905.

3 - ibid, p12.

4 - ibid, p25.

5 - Laila Lalami, The Moor's Account, Reading: Periscope Edition, 2015. P113.

6 - ibid, p115.

7- Jean François Lyotard, The Post-Modern Condition : A Report on Knowledge, Translation from French by Geoff Benington and Brian Massumi, Forward by Fredric Jameson, Manchester: Manchester University Press, 1984, Volume 10, Pp 120-126. Pdf format, from https://monoskop.org/images/e/e0/Lyotard_Jean-

Francois The Postmodern Condition A Report on Knowledge.pdf

8. Edward Saì, Culture and Imperialism, New York: Vintage Books (A division of Random House, Inc.), 1994. $1^{\text {st }}$ Edition. P6.

9ـ محمد بو عزة، "سرديات ثقافية من سياسات الهوية إلى سياسات الاختلاف"، الرباط ــ الجز ائر : دار الأمان ـ منشورات الاختلاف ، 2014، ط1، ص ص 38.

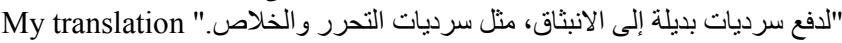


women who were enslaved, deported from different parts of Africa to Seville and other European cities, and were then forced to exile in miserable conditions on board of inhumanly overcrowded ships to the New World; a case in point here is a scene of the slave auction in Seville:

"Swatting flies, the auctioneer looked displeased with the price he had received. He called out for the first of the four women in our group. Without warning, he lifted her dress up. He held her breast in his palm and said she was young and healthy and could bear many children. In her shame, she could only stare at the ground as the boys in the crowd jeered and the girls muffled their giggles. At that moment, I gave many thanks to God that I was not born a woman and did not have to suffer her humiliation."1

Baptized as Elena, brought from Singhana, a sub-Saharan land, and sold separately with her two daughters, Ramatullai leads a life of an enslave woman. Her husband was killed by a Portuguese soldier upon showing the first sign of resistance. Along with Mustafa, Ramatullai was meant to satisfy the short-errands and servitude of Rodriguez's wife Dorotea. Ramatullai's attempt to get in touch with one of her daughter's through a letter written by Mustafa in Arabic proved futile. What adds to her agony is that she has to endure her master's raping in silence as Mustafa expresses his aguish about her:

"Ramatullai did not speak of the violations she endured, and I did not bring them up, but the image tortured me that night and many nights to come."

The story of Ramatullai is the embodiment of the female 'double colonization'; Bill Ashcroft asserts that the term refers to "both the colonial domination of empire and the male domination of patriarchy." 3 Ramatullai was, therefore, denied any human existence as her master Rodriguez treated her as a sex object. On her part, Dorotea Rodriguez scolds and punishes Ramatullai at the slightest mistake.

\section{1- Undermining the stereotypical image of the Red Indians:}

From the very beginning of the "Story of La Florida", the narrator Mustafa discloses the representation that his master and his friends had about the Red Indians:

"The Indians, they said, had red skin an no eyelids, they were heathens who made human sacrifices and worshipped evil-looking gods; they drank mysterious concoctions that gave them visions; they walked about in their natural state, even the women." 4

Nevertheless, these pre-conceived representations and stereotypes about the natives blurred at the narrator's first contact with the natives as he says:

"The stories I had heard about the Indians had me expecting something incredible, fire-breathing jinns perhaps, but these men looked harmless to me - especially next to the Castilian soldiers. Still, they were tied up and brought to Senor Narvaez." 5

Furthermore, the Castilian officials denied the fact that the Indians could have art, music or architecture of any kind. Yet, the denegation of the Indian culture is underpinned by the narrator as he witnessed a procession of flute players playing a beautiful melody. He gave minute descriptions of the beautifully adorned animal hides that they dressed. As for architecture, near the centre of Apalache the soldiers found a skilfully built pyramid with a wooden staircase and chiselled door. This shows, however, that the Indian culture has its own specificities which prove that it cannot be pointed out as primitive.

\section{2- Azemmur as a land of cosmopolitanism}

Prior to the Spanish and Portuguese intervention in the Moroccan territories, Mustafa sheds light on the specificities of Moroccan society at the beginning of the sixteenth century. Different religious and ethnic groups lived in harmony. A case in point in the novel is a scene that epitomizes tolerance among Muslims, Jews and Christians. When Mustafa's father was hit with a sword by a Portuguese soldier for arguing against the detention of a chained girl, and for claiming his priority to get on a barge to cross Umm er-Rbi' River. However, Mustafa reports that his father had a narrow escape thanks to the intervention, diagnosis and medical treatment of a Jewish doctor:

"The doctor was a Jew, a man by the name of Benhaim al-Gharnati, whose reputation had extended throughout the city in just a few short years. (Knowing of my father's resentment of refugees, however, no one told him that his doctor was originally from Granada.) (.....) The wound was very deep, the sword having gone through all the way to the other side, and strips of skin were floating in the puddle of blood. The doctor cleaned the wound and dressed it, but warned that my father was showing signs of disease." 6

Symbolically speaking, the medical treatment that the Jewish doctor had provided for the wounded Muslim for over a week shows that sixteenth century Moroccan society was made up of an amalgam of ethnic groups who

\footnotetext{
1. Laila Lalami, The Moor's Account, Reading: Periscope Edition, 2015. P140.

2 - ibid, p180.

3 - Bill Ashcroft, Gareth Griffiths and Helen Tiffin, Post-Colonial Studies: The Key Concepts, London and New York: Routledge, Second Edition, 2007. P.66.

4 - ibid, p2.

${ }^{5}$ Ibid, p10.

6 - ibid, p36-7.
} 
tolerated each other albeit their religious and racial difference.

Multiplicity and difference are two main characteristics of Sixteenth century Morocco. Moroccan society subsumes different ethnic groups whose language variations differ from one region to the other. For instance, as slaves from different nationalities were brought into a cathedral in Seville before they were deported to the New World, in Mustafa's group, there were four women who spoke a different variation of Tamazight as he states: "I had trouble speaking to them, on account of the fact that they spoke a different variety of Tamazight than I did."

II-Symbolism and the anthropological side in the novel:

In this part, I will display the signification of the creaky blue door as a leitmotiv that reiterates throughout the novel; I will also cast more emphasis on the specificities of the sixteenth-century Moroccan culture.

\section{1- Signification of 'the creaky blue door':}

One of the symbolic elements that recur throughout the novel is 'the creaky blue door'. When Mustafa was crying over his father's death, he fainted and his relatives carried him through the creaky blue door of the house. ${ }^{2}$ In "The Story of the Sale", the narrator marks the scene when he was leaving his homeland for good:

"When I finally got up to leave, my mother stood in the doorway, silhouetted by the light from the courtyard. This is the image of her that I still carry with me, all these years later. She was still calling my name when I closed the blue door behind me."3

From a postcolonial perspective, 'the creaky blue door' embodies a liminality, as Bill Ashcroft puts it:

"The importance of the liminal for post-colonial theory is precisely its usefulness for describing an 'inbetween' space in which cultural change may occur: the transcultural space in which strategies for personal or communal self-hood may be elaborated, a region in which there is a continual process of movement and interchange between different states." 4

As such, the creaky blue door, therefore, symbolizes a threshold that separates two different worlds: The outside world which represents slavery and a life of misery, and the household which is a warm and secure refuge for the family gathering. According to Zhang Haibing, the blue colour symbolizes "tranquillity, melancholy, loneliness, and fantasy." " Thus, this scene foreshadows the life of slavery and melancholy awaiting Mustafa upon his departure from Azemmur.

\section{2- A glimpse on Moroccan culture:}

In his exile in Seville and in the New World, Mustafa introduces different cultural capsules that he recalls from his homeland Azemmur, such as traditions and eating habits. In one of the scenes, he depicts the family gathering over a dish of couscous and the rules of etiquette that accompanies it, which shows the hospitability of Moroccans. Apart from this, in the market, the narrator depicts some practices that are related to medicine and healthcare:

"There, I watched fortune-tellers, faith healers, herbalists, apothecaries and beggars. They promised a healthy child, a painless life, a pliant husband, a dutiful wife or a path to heaven." 6

In one of the scenes of the market, Mustafa witnessed the process of healing his father with cupping or Hijama. "It improves the flow of blood in your body, it builds up your endurance,"" the healer says. Once the doctor's treatment proves futile, some people opt for maraboutic traditions. They visit shrines of saints for they believe that their benediction may ward off some omen or evil spirit. A case in point here is Mustafa's mother who visited Mawlay Abu Shuaib's tomb seeking his intercession, but Mustafa's father "only regressed with each passing day."

\section{III- Power negotiation through storytelling:}

The nexus of power and knowledge is one of the tenets of the Western mega-discourse. The western subject tries to maintain their supremacy over other races through the power of naming. Once in Spain, Mustafa ibn Muhammad was baptized and ascribed a new name: Estebanico; it is an attempt to cut off Mustafa from his past, cultural and religious roots as he relates: "I had entered the church as the servant of God Mustafa ibn Muhammad ibn Abdussalam al-Zemori; I left it as Esteban. Just Esteban - converted and orphaned in one gesture."'

By the same token, villages, rivers and geographical locations were named by the Castilian colonizers, such

\footnotetext{
1 - ibid, P136-7.

2 - ibid, P98.

3 - ibid, P101.

4 - Bill Ashcroft, Gareth Griffiths and Helen Tiffin, Post-Colonial Studies: The Key Concepts, London and New York: Routledge, Second Edition, 2007. P.117.

5 - Zhang Haibing, "Symbolic Meanings of Colors in The Geat Gatsby", an article published in Studies in Literature and Language, Vol. 10, No 6, 2015 pp. 38-44. Published online on 26 June 2015.

6 - Laila Lalami, The Moor's Account, Reading: Periscope Edition, 2015. P40.

7 -ibid, p42.

8 -ibid, p96.

9 - ibid, p 136.
} 
as the village that was named Santa Maria", and the "river which was named in honour of the dead man: Rio Velazquez"2. Naming a geographical feature is one way of taking hold of it. What is more, the Western subject manifests their colonial desire to wipe out the slave's native identity. This refers us to Robinson Crusoe, the main character in Daniel Defoe's novel Robinson Crusoe, who embarks on a slave gathering expedition to West Africa, but ends up shipwrecked on an island, he caught sight of some cannibals with their victims. Crusoe saved one of the victims as he affirms: "I let him know his name should be Friday.(...) I likewise taught him to say Master"3. The Western subject of enunciation is, however, challenged and decentred by the slave Mustafa through mastery of Indian languages and storytelling.

The notion of storytelling recurs so often in the novel that it has become a leitmotiv. It is a skill that Mustafa had acquired and enhanced from the stories his mother used to nourish him with. These stories are full of wisdom and moral values. Mustafa's father wanted his son to become a notary. The latter was reluctant to fulfil that wish and took up trade, which induced his mother to tell him the story of the girl embroiderer whose excessive curiosity to see the luxuries of the sultan's palace led her to disguise as a musician, but when she was unmasked, she was thrown out of the palace. As to the moral value of this story Mustafa wonders:

"My mother had accustomed me to fairy tales in which it was easy for me to imagine myself, so I remained quiet as I thought about the Story of the Embroiderer and the Sultan. Was I the embroiderer, who should have been content with her gift and not sought out that which was beyond her reach?"4

Closely bound up with the concept of storytelling is the voicing of Mustafa. As a slave he was not allowed to speak, let alone give his opinion on minor matters. Yet, during the time of ordeal, the expedition men got stuck on the beach of Aute, they were in a dilemma whether to wait for ships until they run out of their food reserves or march past the bay until they reach the port of Panuco. At that particular moment, Mustafa spoke:

"There is another way, I said. We can build rafts.

All eyes fixed themselves upon me. So accustomed were the Castilians to my silence - one or two of the lieutenants might even have thought me deaf or dumb."5

From that particular moment on, a change in the axes of power took place. The worse the Castilians conditions were, the more powerful Mustafa's personality became. He is a multilingual figure. He speaks Arabic, Tamazight, Spanish, and a great deal of Portuguese. With exposure to Indian languages, he was able to expand his vocabulary of the language of the Capoques; he also mastered the language of the Carancahua. As a result, he could fluently engage in conversations with the natives. He could fluently engage in conversations with the natives. With all the hardships that the Castilians had undergone, the pivot of power is being transferred to Mustafa's side; thus, his voice is heard among the Castilians. He gained much freedom as he indulges with Diego in a discussion about the wooden birds he carved. Mustafa told Diego about the story of his two brothers Yussuf and Yahya and how they would ask him to carry them after being exhausted from swimming in the Umm er-Rbi' River ${ }^{6}$.

Despite his displacement to a completely strange land, Mustafa's strength lies in his right to own his story. In one of the scenes of the novel, Dorantes asks Mustafa to tell him his story: "What did he want from me? Was it not enough that he owned me and could dispose of me as he wished? Now he wanted that which had always been my own - my story."7 Mustafa affirms that the pleasure of a story resides in telling it.

Still, more challenge and defiance is manifested from the part of Mustafa towards the Western whites. As Dorantes argued with Cabeza de Vaca about whether they would join the Capoques tribe or the Han tribe, Mustafa intervened and brought forth his sound argument vis-à-vis Cabeza de Vaca; Mustafa was for joining the Capoques, because they provided them with food and shelter, and if they had joined the Han tribe, it would have been an insult to the Capoques.

Last but not least, of crucial significance to Postcolonial theory is the notion of hybridity. It entails that there are no clear-cut boundaries between the culture of the Self and that of the Other. In this context, Homi Bhabha defines it in his The Location of Culture as follows:

"Colonial hybridity is not a problem of genealogy or identity between two different cultures which can then be resolved as an issue of cultural relativism. Hybridity is a problematic of colonial representation and individuation that reverses the effects of the colonialist disavowal, so that other 'denied' knowledges enter upon the dominant discourse and estrange the basis of its authority - its rules of recognition." 8

Given the fact that hybridity presupposes being situated in a third space, I contend that Mustafa is a hybrid figure. My thrust of argument is that he has become knowledgeable about the languages of cultures of the Spanish

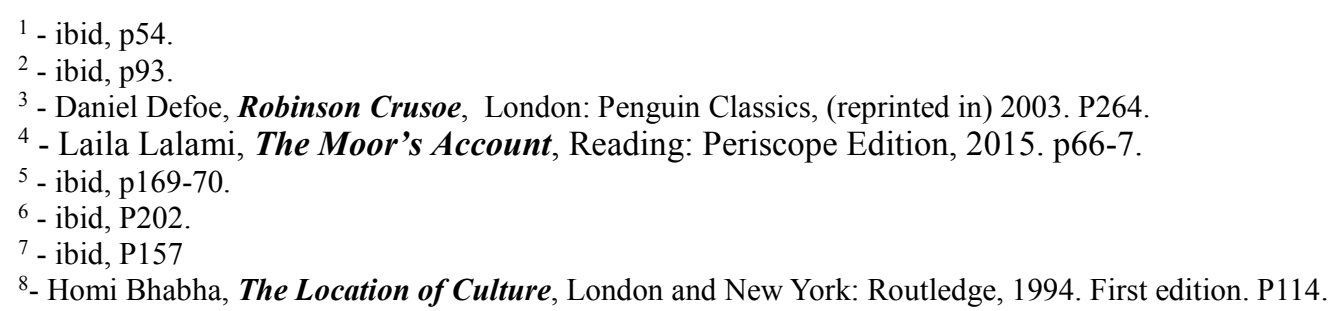


society as well as that of the Indian tribes, and at the same time, he adheres to his Moroccan culture. His mastery of the Carancahua language and the Capoque tongue has enabled him to break free from the yoke of subalternity and usurp the role of interpreter between the Indians and the Castelians: "As for me, I stood in the space between the Castelians and the Carancahuas, waiting to translate." (Lalami, 2015: 294-5). Mustafa's fame has spread all over the Indian tribes.

Mustafa is aware of the role assigned to him as a storyteller, for he tries to establish a close rapport with the reader based on telling the slightest details of his story as he asserts: "Reader, it is not easy for me to confess that I served the forbidden drink, but I have decided in this relation to tell everything that happened to me, so I must not leave out even such a detail."

Story-telling has become a sine-qua-non ${ }^{2}$ condition for Mustafa to survive. Not only does Mustafa restore his subjectivity, but his status is also elevated among the native tribes as they appreciate the stories he tells them around the fire at night. As a healer, Mustafa exploits the therapeutical effect of stories to heal people, a skill that he had learned in Azemmur from his mother as she used to tell him stories:

"All I knew was that the weight on my chest no longer felt heavy, because my mother's stories always entertained me, and, by so doing, soothed me."

Towards the last chapters of the novel, the power of storytelling is given much credit. With a consent from a friar, Mustafa set off with his wife to the neighbouring villages in prospect of gold. Every now and then he sends messengers delivering messages about lack of existence of gold in those villages. He felt somehow free as he says: "At last, I was free of the Amigos, who were not amigos. And my involvement with the empire was finally over."

Storytelling is part and parcel of the Moroccan cultural heritage as stories are handed down from generation to generation through the stories that mothers and grandmothers tell their children, and also the 'halqa' tradition. Following this tradition Mustafa intends to tell his wife Oyomasot a story: "Listen, I said. Let me tell you a story you can tell our child." " He wants to teach his child how not to put his life in the hands of another man.

To attain complete freedom and autonomy, Mustafa was obliged to alter his identity as Estebanico the slave by making up a fictitious story feigning that Estebanico was killed by the Indians of Hawikuh. He told Ahwu, the cacique of Zunis, that if the messengers knew how to tell the story, it would be successful. In that sense, Ahku's only stratagem of salvation was to create a fiction. Ultimately, storytelling becomes a hegemonic discourse which enabled the narrator to restore his identity as Mustafa ibn Muhammad.

\section{Conclusion}

In sum, this study has proven so far that The Moor's Account is a postcolonial novel which deconstructs and problematizes the Eurocentric discourse of imperialism by giving voice to a slave to relate history that had been sunk into oblivion for over five centuries. In so doing, Laila Lalami intertwined history with historical fiction. Her narrative is characterized by ruptures, breaks and discontinuities and it does not yield itself to the hegemony of the Western subject. What Lalami is driving at is that the American nation was constructed by peoples from different nationalities who were enslaved, tortured and forced to work in servitude and agriculture, namely cotton plantations. Besides, she sheds light on the lifestyle of the American Indians and their annihilation by the Western whites.

It follows, then, that Laila Lalami's The Moor's Account functions as a palimpsest for it carries intertextual traces of Cabeza de Vaca's chronicle. Lalami puts it under scrutiny and questions its tenets. This, yet subtle, similitude between the structure of La Rélacion and that of the Moor's Account is alluded to by Linnéa Ungewitter:

"The chapters all deal with a certain stage of the expedition, and are named accordingly. Cabeza de Vaca's text has one chapter named "the Life of the Mariams and Yguaces", and Laila Lalami has one has one chapter, or rather story, called "The Story of the Yguaces". It seems as if Lalami is telling us that just as Mustafa's, de Vaca 's chapters are simply subjective stories."

As a postcolonial writer, Laila Lalami challenges the monolithic European discourse deployed in Cabeza de Vaca's historical account; she opens up the possibility for a myriad of small narratives to emerge. As such, apart from Mustafa"s account, Lalami gives much room for Ramatullai to voice her unsaid story.

\section{References}

$>$ Ashcroft, Bill, Griffiths, Gareth, Tiffin, Helen, Post-Colonial Studies: The Key Concepts, London and

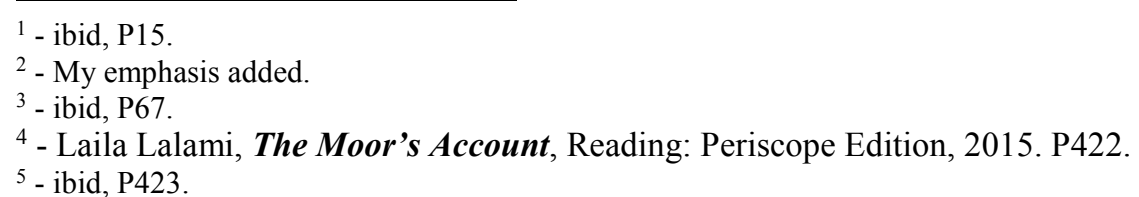

6 - Linnéa Ungewitter, The Story of How Estebanico Became Mustafa's in Laila Lalami's The Moor's Account: Retelling Stories in a Post-Colonial Light, Degree project in English Literature submitted to "Centre for Languages and Literaure English Studies, 2016 
New York: Routledge, Second Edition, 2007. P.117.

$>$ Bhabha, Homi, The Location of Culture, London and New York: Routledge, 1994. First edition. P114.

$>$ Cabeza de Vaca, Alvar Nunez, The Journey of Alvar Nunez Cabaza de Vaca (1542), translated from his Own Narrative by Fanny Bandelier, New York: A. S. Barnes and Company, 1905.

$>$ Defoe, Daniel, Robinson Crusoe, London :Penguin Classics, (reprinted in) 2003.

$>$ Elboubekri, Abdellah, "Whichever way you turn, there is the face of God' diaspora, memory, and historiography from the margin in The Moor's Account by Laila Lalami”, an article published in African and Black Diaspora: An International Journal on September $3^{\text {rd }}, 2016$. P5.

$>$ Fergusson, Rosalind (editor), The Penguin Dictionary of English Synonyms and Antonyms, London: Penguin Books, 1992.

$>$ Lalami, Laila The Moor's Account, Reading: Periscope Edition, 2015.

$>$ Lyotard, Jean François, The Post-Modern Condition : A Report on Knowledge, Translation from French by Geoff Benington and Brian Massumi, Forward by Fredric Jameson, Manchester: Manchester University Press, 1984, Volume 10, Pp 120-126. Pdf format, from: https://www.abdn.ac.uk/idav/documents/Lyotard___Postmodern_Condition.pdf

$>$ Haibing, Zhang, « Symbolic Meanings of Colors in The Geat Gatsby”, an article published in Studies in Literature and Language, Vol. 10, No 6, 2015 pp. 38-44. Published online on 26 June 2015.

$>$ Hornby, A. S, Oxford Advanced Learner's Dictionary of Current English, edited by Sally Wehmeier, Oxford: Oxford University Press, 2000, Sixth Edition.

$>$ Said, Edward, Culture and Imperialism, New York: Vintage Books (A division of Random House, Inc.), 1994. $1^{\text {st }}$ Edition.

$>$ Spivak, Gayatri Chakravorty, « Can the Subaltern Speak?», from Colonial Discourse and Post-Colonial Theory: A Reader, edited by Patrick Williams and Laura Chrisman, New York: Colombia University Press, from: http://planetarities.web.unc.edu/files/2015/01/spivak-subaltern-speak.pdf

> Ungewitter, Linnéa, The Story of How Estebanico Became Mustafa's in Laila Lalami's The Moor's Account: Retelling Stories in a Post-Colonial Light, Degree project in English Literature submitted to "Centre for Languages and Literaure English Studies, Lund University, 2016.

References in Arabic:

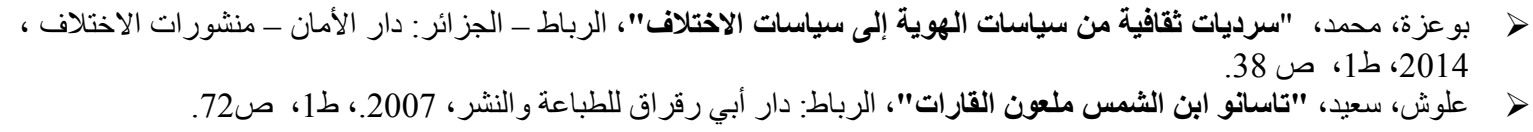

